Lesia Savchenko, PhD, Associate Professor, Department of Quality, Standardization and Certification of Medicines IQIP, National University of Pharmacy, Pushkinska str., 53, Kharkiv, Ukraine, 61002

E-mail: savchenkolesia@gmail.com

Kateryna Uminska, Department of Quality, Standardization and Certification of Medicines IQIP, National University of Pharmacy, Pushkinska str., 53, Kharkiv, Ukraine, 61002

Nataliia Bevz, PhD, Associate Professor, Department of Pharmaceutical Chemistry, National University of Pharmacy, Pushkinska str., 53, Kharkiv, Ukraine, 61002

E-mail: natali.bevz.60@gmail.com

Victoriya Georgiyants, Doctor of Pharmaceutical Sciences, Professor, Department of Pharmaceutical Chemistry, National University of Pharmacy, Pushkinska str., 53, Kharkiv, Ukraine, 61002

E-mail:vgeor@ukr.net

UDC 615.453.3

DOI: $10.15587 / 2519-4852.2018 .122007$

\title{
STUDY OF EXCIPIENTS QUANTITIES INFLUENCEIN THE COMPOSITION OF THE POWDER IN SACHET PACKAGES
}

\author{
(c) O. Tryhubchak, S. Gureyeva, O. Yuryeva
}

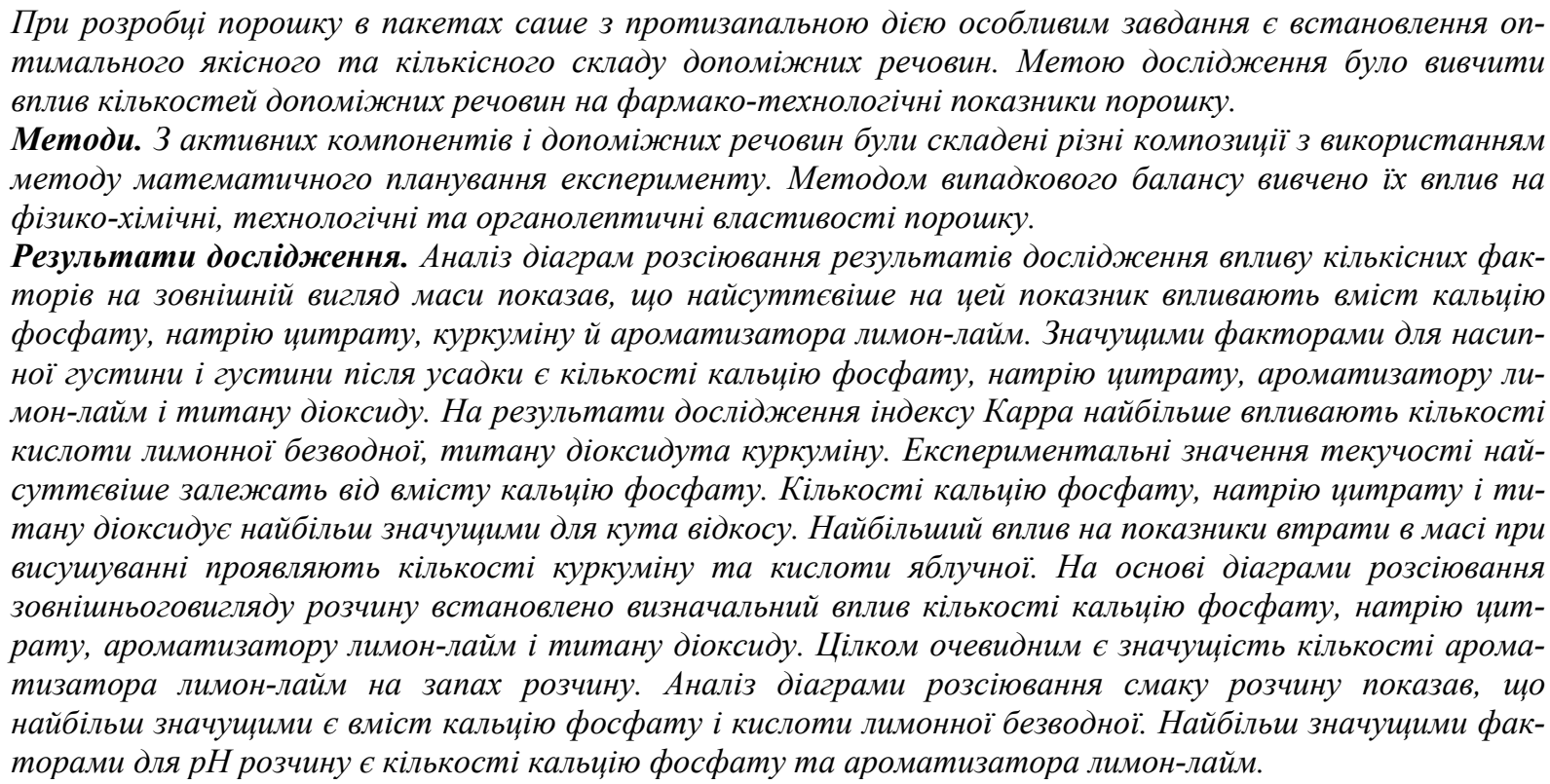

Висновки. Досліджено вплив кількостей допоміжних речовин на фармако-технологічніта органолептичні властивості порошку в пакетах саше склад саше

Ключові слова: порошок, саше, кількість допоміжних речовин, фармако-технологічні показники, випадковий баланс

\section{Introduction}

Powders in packs are well appreciated by patients, because they have the combined benefits of tablets (precise dosage) and the possibility of easier ingestion (do no need to swallow the tablets) [1].

\section{Statement of the problem}

During developing a drug, you must take into account a number of key moments. After all, the purpose of pharmaceutical development is not only the creation of an effective and safe drug, but also the organization of appropriate conditions of the production process, which would ensure its reproducibility. The choice of the optimal composition of the drug and the development of technology makes it possible to establish a range of permissible values of the parameters of the process and components of the recipe, the observance of which guarantees the conformity of the final product to the requirements of the specification [2].

In order to develop a drug with anti-inflammatory properties, active pharmaceutical ingredients were selected, depending on the mechanisms of action. When creating powder in sachets with $0.325 \mathrm{~g}$ of paracetamol, $0.05 \mathrm{~g}$ ascorbic acid, $0.01 \mathrm{~g}$ of phenylep- 
hrine hydrochloride and $0.02 \mathrm{~g}$ of pheniramine maleate, first of all, the ratio of active pharmaceutical ingredients and their physic-chemical properties were taken into account. When developing the powder, a special task is to establish an optimal qualitative and quantitative composition of excipients [3]. Based on the study of technological characteristics of powders were identified excipients.

\section{Analysis of recent research and publications}

In work $[4,5]$, using the plans of mathematical planning of the experiment, the influence of quantitative factors on the basic pharmaco-technological parameters of the tablets was investigated, which allowed to reveal and substantiate the correlation of excipients for the development of the optimal composition of solid dosage forms. On an example of optimizing the composition of rapidly soluble tablets of clonazepam, a mathematical model was proposed to be tested by controlling the pharmaco-technological parameters [6].

Research, using mathematical methods of planning (random balance method, factor experiment, the Boxes-Wilson method), are successfully used to optimize various technological processes. The main advantage of the methods of mathematical planning in comparison with the classical methods of research is the possibility of simultaneous study of a large number of factors operating in the system [7].

Using the scientific approaches of mathematical planning of the experiment, namely, the method of random balance, authors [8-10] studied the influence of quantitative factors on the main indicators of the quality of drugs. The most significant factors influencing the formulation and the main indicators of quality of developed preparations in the form of suspensions $[8,9]$ and tablets [10] were determined.

\section{Identification of aspects of the problem un- solved previously}

In previous studies, the effect of nature of $27 \mathrm{ex}-$ cipients on the pharmaco-technological properties of the powder in sachet packs was studied. According to the obtained results, the excipients that have the most significant influence on the pharmaco-technological parameters of the medicinal form were selected. Then it is necessary to study the quantitative characteristics of the excipients, since when they change in composition will change the pharmacological and technological properties of the powder. Study of pharmaco-technological parameters of the dosage form will allow to optimize the excipients quantity in the composition and to manage the quality of the drug.

\section{Objective statement of the article}

The aim of the work was to study the effect of excipients quantity on the pharmaco-technological parameters of the powder in sachet packs.

\section{search \\ 6. Presentation of the main material of the re-}

From the active components and excipients, different compositions were compiled using the method of mathematical planning of the experiment. By accidental balance method, their influence on physic-chemical, technological properties of powders and quality indicators of a solution were studied.

Based on the results of the previous experiment on the influence of qualitative factors, it was gotten excipients quantity for use during making research and shown in Table. 1.

Using the random balance method [7], a research plan was drawn up (Table 2). The average weight of $22.13 \mathrm{~g}$ was regulated by the quantity of powdered sugar.

Table 1

Factors and their levels in the study of quantitative characteristics of excipients in powder in sachet packs

\begin{tabular}{|c|l|c|c|c|}
\hline \multirow{2}{*}{ Designation of the factor } & \multicolumn{1}{|c|}{ Factor } & \multicolumn{3}{|c|}{ Level of the factor } \\
\cline { 3 - 5 } & & Lower «-» & Basic «0»» & Upper «+» \\
\hline $\mathrm{x}_{1}$ & Quantity of calcium phosphate, $\mathrm{g}$ & 0.0820 & 0.7000 & 1.3180 \\
\hline $\mathrm{x}_{2}$ & Quantity of acid citric anhydrous, $\mathrm{g}$ & 0.6500 & 0.9360 & 1.2220 \\
\hline $\mathrm{x}_{3}$ & Quantity of malic acid, $\mathrm{g}$ & 0.0500 & 0.0900 & 0.1300 \\
\hline $\mathrm{x}_{4}$ & Quantity of sodium citrate, $\mathrm{g}$ & 0 & 0.0605 & 0.1210 \\
\hline $\mathrm{x}_{5}$ & Quantity of curcumin, $\mathrm{g}$ & 0.0213 & 0.0383 & 0.0400 \\
\hline $\mathrm{x}_{6}$ & Quantity of lemon-lime flavor, $\mathrm{g}$ & 0.1915 & 0.2000 & 0.2085 \\
\hline $\mathrm{x}_{7}$ & Quantity of titanium dioxide, $\mathrm{g}$ & 0.0014 & 0.0032 & 0.0050 \\
\hline
\end{tabular}

Table 2

The experiment planning matrix, the results of the research of powder in sachets

\begin{tabular}{|c|c|c|c|c|c|c|c|c|c|c|c|c|c|c|c|c|c|c|}
\hline batch & $\mathrm{x}_{1}$ & $\mathrm{X}_{2}$ & $\mathrm{x}_{3}$ & $\mathrm{x}_{4}$ & $\mathrm{X}_{5}$ & $\mathrm{X}_{6}$ & $x_{7}$ & $\mathrm{y}_{1}$ & $\mathrm{y}_{2}$ & $\mathrm{y}_{3}$ & $\mathrm{y}_{4}$ & $\mathrm{y}_{5}$ & $\mathrm{y}_{6}$ & $\mathrm{y}_{7}$ & $\mathrm{y}_{8}$ & $\mathrm{y}_{9}$ & $\mathrm{y}_{10}$ & $\mathrm{y}_{11}$ \\
\hline 1 & - & - & - & + & + & + & - & 5 & 0.6086 & 0.8844 & 31.18 & 56.8 & 48.3 & 0.30 & 5 & 5 & 4 & 3.05 \\
\hline 2 & - & + & - & + & - & + & - & 4 & 0.6403 & 0.8658 & 26.05 & 44.9 & 47.5 & 0.31 & 5 & 4 & 5 & 2.78 \\
\hline 3 & + & - & - & - & - & - & + & 5 & \begin{tabular}{|l|}
0.7403 \\
\end{tabular} & 1.0193 & 27.37 & 52.7 & 41.0 & 0.32 & 4 & 4 & 3 & 4.01 \\
\hline 4 & + & + & - & - & + & - & + & 5 & 0.7393 & 1.0071 & 26.59 & 50.1 & 40.5 & 0.46 & 4 & 4 & 5 & 3.74 \\
\hline 5 & - & - & + & + & - & - & + & 4 & 0.6502 & 0.8824 & 26.31 & 17.5 & 46.9 & 0.37 & 5 & 4 & 4 & 3.10 \\
\hline 6 & - & + & + & - & + & + & - & 5 & 0.6187 & 0.8517 & 27.36 & 18.4 & 46.6 & 0.46 & 5 & 5 & 5 & 2.58 \\
\hline 7 & + & - & + & + & + & - & - & 5 & 0.7246 & 1.0016 & 27.66 & 69.1 & 41.7 & 0.46 & 4 & 4 & 3 & 3.98 \\
\hline 8 & + & + & + & - & - & + & + & 4 & 0.7444 & 1.0066 & 26.05 & 66.6 & 41.4 & 0.39 & 4 & 5 & 3 & 3.70 \\
\hline 9 & 0 & 0 & 0 & 0 & 0 & 0 & 0 & 5 & 0.6944 & 0.9742 & 28.72 & 62.6 & 43.6 & 0.50 & 4 & 4 & 5 & 3.60 \\
\hline 10 & 0 & 0 & 0 & 0 & 0 & 0 & 0 & 5 & 0.7075 & 0.9988 & 29.16 & 57.6 & 45.2 & 0.42 & 4 & 4 & 4 & 3.60 \\
\hline
\end{tabular}

Notes: $y_{1}$-appearance of the mass, points; $y_{2}-$ bulk density, $g / m l ; y_{3}-$ density after shrinkage, g/ml; $y_{4}-$ Carr's index, \%; $y_{5}-$ flow rate, s/100 g; $y_{6}$ - slope angle; $y_{7}$ - mass loss during drying, $\% ; y_{8}$ - appearance of the solution, points; $y_{9}-$ the smell of the solution, points; $y_{10}-$ taste of the solution, points; $y_{11}-p H$ of the solution 
Experimental studies of pharmaco-technological quality indices were carried out in accordance with pharmacopoeial methods, in particular: mass loss during drying, bulk density, density after shrinkage, flow, slope angle and $\mathrm{pH}$ of a solution $[11,12]$. The technological properties of the powder masses and the physical characteristics of the solution from the contents of the sachet package in $200 \mathrm{ml}$ of purified water were studied.

Determination of significant factors was carried out using scattering diagrams. The median value indicated the significance of the factor. The significance of the selected effects was verified using Student's criterion.

Test results are presented in Table 2.

The analysis of the scattering diagram of the results of the study of the influence of quantitative factors on the appearance of the mass $\left(\mathrm{y}_{1}\right)$ showed that the most significant of this indicator is infused with calcium phosphate, sodium citrate, curcumin and lemon-lime flavor. With an increase in the quantity of calcium phosphate, curcumin and the study of the lower levels of factors $\mathrm{x}_{4}, \mathrm{x}_{6}$, the intensity of colour and appearance of the powder is significantly increased. The analysis of the influence of other factors showed their insignificant effect on this indicator.

The influence of quantitative factors on the bulk density $\left(\mathrm{y}_{2}\right)$ and the density after shrinkage $\left(\mathrm{y}_{3}\right)$ is given in Fig. 1.

From the diagrams it is seen that the significant factors are $\mathrm{x}_{1}, \mathrm{x}_{4}, \mathrm{x}_{6}, \mathrm{x}_{7}$. Increasing the quantities of calcium phosphate and titanium dioxide, as well as reducing the content of sodium citrate and flavor of lemon-lime is accompanied by an improvement in the studied parameters.

Analysis of the scattering diagram of the Carr's index $\left(\mathrm{y}_{4}\right)$ showed that the results of the study are most influenced by the factors $\mathrm{x}_{2}, \mathrm{x}_{7}$ and $\mathrm{x}_{5}$. With an increase in the content of lemon acid anhydrous and titanium dioxide, the bulk density of the powder mass improves from $27.5 \%$ to $26.3 \%$. The introduction of a greater quantity of the curcumin is accompanied by an increase in the Carr's index from $26 \%$ to $27 \%$, which indicates deterioration of mass flowability and may be the cause of deterioration of filling in the packaging stage.

The analysis of the scattering diagram of the results of the study of the effect of quantitative factors on the flow $\left(\mathrm{y}_{5}\right)$ showed that the experimental values most significantly depend on the quantity of calcium phosphate. The increase in the factor $\mathrm{x}_{1}$ is accompanied by a deterioration of the powder flowability from $32.0 \mathrm{~s} / 100 \mathrm{~g}$ to $59.0 \mathrm{~s} / 100 \mathrm{~g}$. This indicator is somewhat improved (varies in the range from $51.0 \mathrm{~s} / 100 \mathrm{~g}$ to $42.0 \mathrm{~s} / 100 \mathrm{~g}$ ) with administration of a greater amount of malic acid due to the crystalline structure of its particles.

In assessing the influence of quantitative factors on the slope angle $\left(\mathrm{y}_{6}\right)$, using the scatter diagram, it was noted that the factors $\mathrm{x}_{1}, \mathrm{x}_{4}, \mathrm{x}_{7}$ are the most significant. At the same time, when the content of calcium phosphate and titanium dioxide decreases, the difference in the average from $47^{\circ}$ to $41^{\circ}$. However, the introduction of more sodium citrate is accompanied by opposite changes. It should be noted that the increase in the quantity of lemon-lime flavor improves the slope of the range from $44^{\circ}$ to $47^{\circ}$.
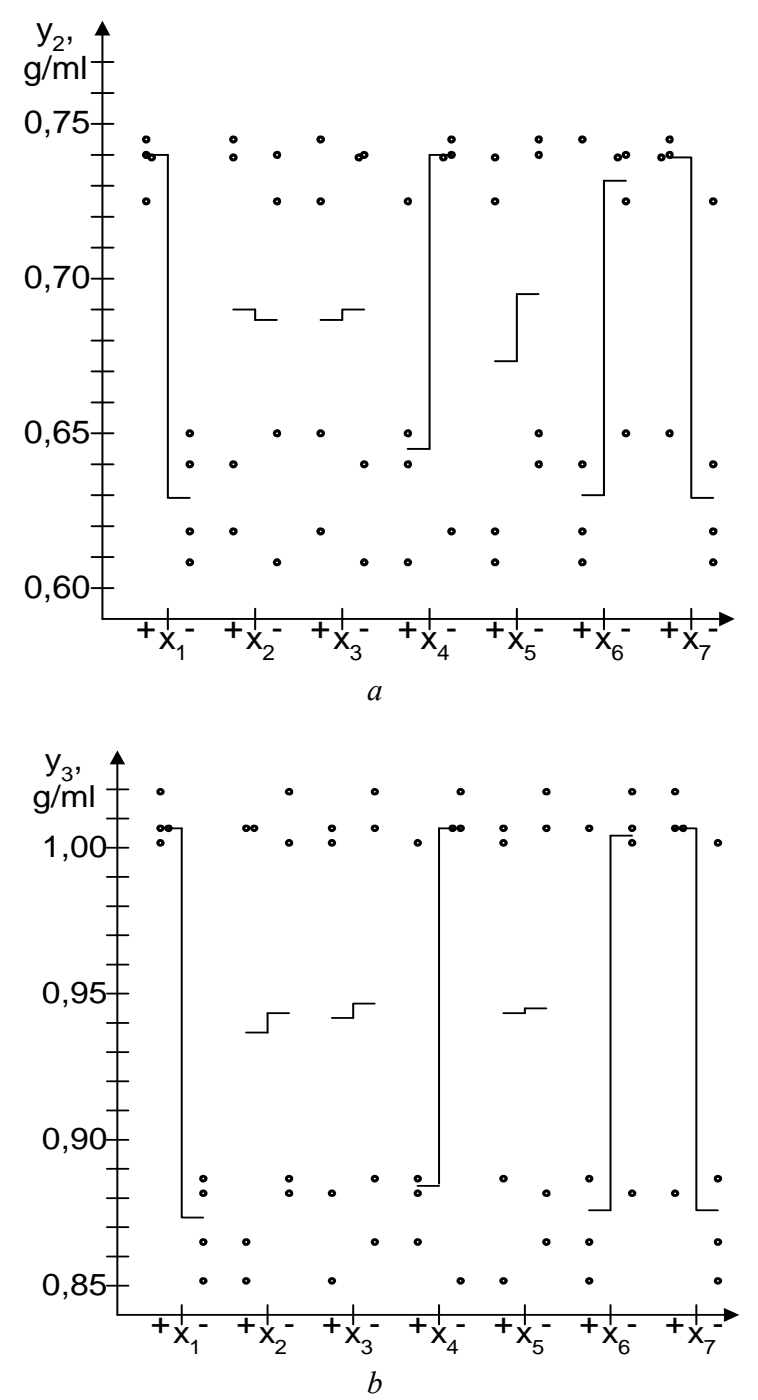

Fig. 1. Diagram of dispersion of the influence of quantitative factors on the density of the powder: $a$ - on the bulk density; $b-$ on the density after shrinkage

Loss in mass during drying is an important indicator of quality, especially in the process of storing powder in sachet packs. High moisture content can cause the powders to soften and impair their characteristics. The influence of quantitative factors on mass loss during drying $\left(\mathrm{y}_{7}\right)$ is shown in Fig. 2.

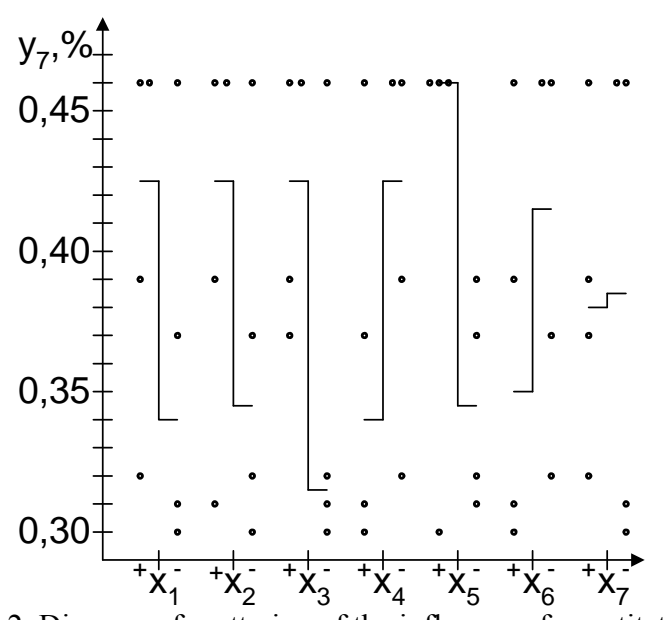

Fig. 2. Diagram of scattering of the influence of quantitative factors on mass loss during drying 
It can be seen from the diagram that the factors $\mathrm{x}_{5}$ and $x_{3}$ show the greatest influence on the mass loss index during drying. The lowest values of this index were observed with the addition of $0.0213 \mathrm{~g}$ of curcumin. The introduction of malic acid at the lower investigated level also significantly reduces the moisture content of the powder. Reducing the quantities of calcium phosphate and citric anhydrous acid leads to an improvement in the investigated index. However, an increase in sodium citrate content and a lemon-lime flavour can reduce the loss of mass in the mass during drying.

For the powder for oral solution important parameters are also organoleptic characteristics of the solution from the content of the sachet pack. In order to quantify their contents, one packet of powder was dissolved in $200 \mathrm{ml}$ of purified water and the solution was analysed in appearance, smell, taste and $\mathrm{pH}$. The first three indicators were evaluated on a 5-point scale. The analysis of the results was carried out using scattering diagrams.

On the basis of the scattering diagram of the appearance of the solution $\left(\mathrm{y}_{8}\right)$, the determining influence of the factors $\mathrm{x}_{1}, \mathrm{x}_{4}, \mathrm{x}_{6}, \mathrm{x}_{7}$ is established. With increasing quantities of sodium citrate and lemon-lime flavor transparent solution with intense coloration was obtained. Administration of higher contents of calcium phosphate and titanium dioxide causes turbidity of the solution.

Obviously, the significance of the quantity of lemon-lime flavor on the smell of the solution $\left(\mathrm{y}_{9}\right)$, and with the increase in its content, the results improve. There is also an insignificant influence of other factors on the smell of the solution.

Analysis of the scattering diagram of the taste of the solution $\left(\mathrm{y}_{10}\right)$ showed that the most significant are the factors $\mathrm{x}_{1}$ and $\mathrm{x}_{2}$. With an increase of the quantity of acid citric anhydrous, there is a sour taste pleasant, and an increase in calcium phosphate content contrary effects on the taste of the solution. Adding more malic acid also causes unpleasant taste sensations. An increase in the quantities of curcumin and lemon-lime flavor add sour taste, and this allows some improvement in the investigated parameter.

One of the most important characteristics was the $\mathrm{pH}$ of the solution $\left(\mathrm{y}_{11}\right)$. It depended on the solubility of the content of the sachet package. At low values, the $\mathrm{pH}$ of the powder was completely dissolved and left no residue. The influence of quantitative factors on the $\mathrm{pH}$ of the solution is shown in Fig. 3.

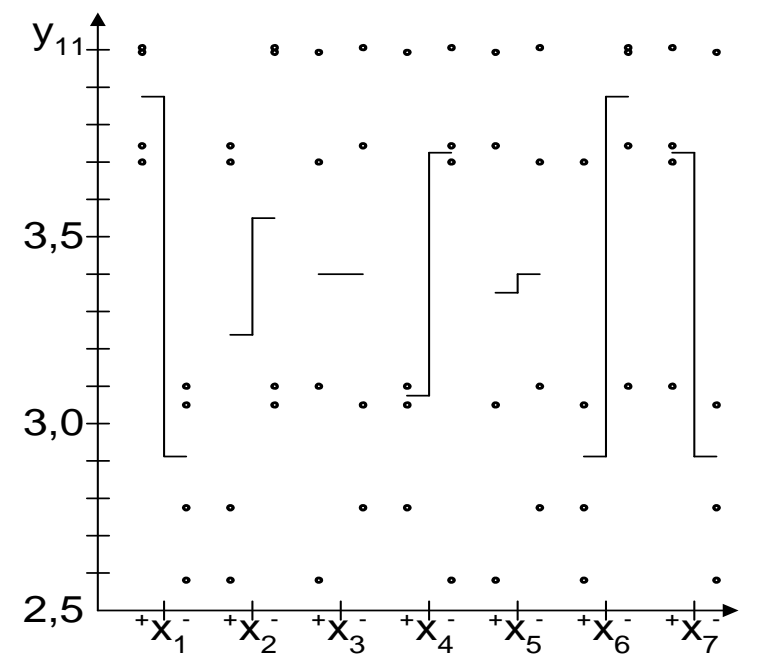

Fig. 3. Diagram of scattering of the influence of quantitative factors on the $\mathrm{pH}$ of the solution

The diagram shows that the most significant factors are $\mathrm{x}_{1}$ and $\mathrm{x}_{6}$. Significant influence is shown by the factors $\mathrm{x}_{7}$ and $\mathrm{x}_{4}$. The lowest $\mathrm{pH}$ values were observed with the addition of $0.0820 \mathrm{~g}$ of calcium phosphate, $0.1210 \mathrm{~g}$ of sodium citrate, $0.2085 \mathrm{~g}$ of lemon-lime flavor and $0.0014 \mathrm{~g}$ of titanium dioxide.

To summarize the experimental data obtained, it was constructed a Table 3 .

Table 3

The results of the experiment are summarized in the development of the composition of the powder in sachets packages

\begin{tabular}{|c|c|c|c|c|c|c|c|}
\hline $\begin{array}{l}\text { Factor/ } \\
\text { indicator }\end{array}$ & $\mathrm{x}_{1}$ & $\mathrm{x}_{2}$ & $\mathrm{x}_{3}$ & $\mathrm{x}_{4}$ & $\mathrm{x}_{5}$ & $\mathrm{x}_{6}$ & $x_{7}$ \\
\hline $\mathrm{y}_{1}$ & $+*$ & 0 & 0 & -* & $+*$ & $-*$ & 0 \\
\hline $\mathrm{y}_{2}$ & $+*$ & + & - & -* & - & -* $^{*}$ & $+*$ \\
\hline $\mathrm{y}_{3}$ & $+*$ & - & - & $-*$ & - & $-*$ & $+*$ \\
\hline $\mathrm{y}_{4}$ & - & $+*$ & + & - & -* & + & $+*$ \\
\hline $\mathrm{y}_{5}$ & -* & + & $+*$ & + & - & + & - \\
\hline $\mathrm{y}_{6}$ & -* & - & 0 & $+*$ & + & $+*$ & -* \\
\hline $\mathrm{y}_{7}$ & -* & -* & _* & $+*$ & -* & $+*$ & + \\
\hline $\mathrm{y}_{8}$ & -* & 0 & 0 & $+*$ & 0 & $+*$ & $-*$ \\
\hline $\mathrm{y}_{9}$ & - & + & + & - & + & $+*$ & - \\
\hline $\mathrm{y}_{10}$ & -* & $+*$ & -* & + & $+*$ & $+*$ & + \\
\hline $\mathrm{y}_{11}$ & -* & + & 0 & $+*$ & + & $+*$ & -* \\
\hline
\end{tabular}

Note: *- significant factor

\section{search}

7. Conclusions and prospects for further re-

1. Quantitative factors of excipients were studied when creating a powder in sachets packages.

2. It was studied the influence of the quantities of excipients on the pharmaco-technological and or- ganoleptic properties of the medicinal product: the appearance of the mass, the bulk density, the density after shrinkage, the Carr's index, the flowability, the slope, the mass loss in drying, the appearance of the solution, the smell of the solution, the taste solution, $\mathrm{pH}$ of the solution. 


\section{References}

1. Gerald G., Klyuyeva N. Mannitol - mnogogrannyy ekstsipiyent dlya proizvodstva tverdykh lekarstvennykh form. Farmatsevticheskaya otrasl. 2015. Issue 5 (52). P. 50-51.

2. Osakwe O. Pharmaceutical Formulation and Manufacturing Development: Strategies and Issues // Social Aspects of Drug Discovery, Development and Commercialization. Academic press, 2016. P. 169-187. doi: 10.1016/b978-0-12-802220-7.00008-9

3. Nastanova 42-3.0:2011. Likarski zasoby. Farmatsevtychna rozrobka (ICH Q8) / ed. Liapunov M. et. al. Kyiv: MOZ Ukrainy, 2011. 42 p.

4. Slipchenko H. D., Ruban O. A., Belei N. M. Optymizatsiia skladu i tekhnolohii tabletok na osnovi sukhoho ekstraktu sholomnytsi baikalskoi // Farmatsevtychnyi chasopys. 2016. Issue 1. P. 50-53.

5. Ravliv Yu. A., Hroshovyi T. A., Tryhubchak O. V. Optymizatsiia skladu i tekhnolohii tabletok na osnovi krioliofilizovanoi ksenodermy svyni // Farmatsevtychnyi chasopys. 2013. Issue 3. P. 55-57.

6. Formulation design and optimization of fast dissolving clonazepam tablets by sublimation method / Suresh S. et. al. // Indian Journal of Pharmaceutical Sciences. 2011. Vol. 73, Issue 5. P. 491-496. doi: 10.4103/0250-474x.98984

7. Matematychne planuvannia eksperymentu pry provedenni naukovykh doslidzhen v farmatsii / Hroshovyi T. A. et. al. Ternopil: TDMU, 2008. 368 p.

8. Kachaput A. I. Izuchenie vliyaniya kolichestvennykh faktorov na osnovnye pokazateli kachestva inektsionnoy suspenzii na osnove betametazona dipropionata i betametazona natriya fosfata // Vestnik farmatsii. 2016. Issue 4 (74). P. 10-17.

9. Zavalko I. V. doslidzhennia vplyvu kilkisnykh kharakterystyk dopomizhnykh rechovyn na osnovni pokaznyky yakosti oftalmolohichnoi/otolohichnoi suspenzii // Zaporizkyi medychnyi zhurnal. 2013. Issue 2 (77). P. 91-93.

10. Kozak I. V., Belei N. M., Hroshovyi T. A. Vplyv kilkisnykh faktoriv na farmako-tekhnolohichni vlastyvosti tabletok ekstraktu shkirky lymona // Farmatsevtychnyi chasopys. 2013. Issue 1 (25). P. 86-89.

11. Derzhavna Farmakopeia Ukrainy. Vol. 1 Kharkiv: Derzhavne pidpryiemstvo «Ukrainskyi naukovyi farmakopeinyi tsentr yakosti likarskykh zasobiv», 2015. $1130 \mathrm{p}$.

12. European Pharmacopoeia 9th Edition. Vol. 1. Strasbourg: Council of Europe, EDQM, 2016. 1615 p.

Дата надходження рукопису 31.10.2017

Oksana Tryhubchak, PhD, Associate Professor, Central Laboratory of Pharmaceutical Development, Farmak Joint-Stock Company, Frunze str., 63, Kyiv, Ukraine, 04080

E-mail: o.tryhubchak@farmak.ua

Svetlana Gureyeva, Doctor of Pharmaceutical Sciences, Central Laboratory of Pharmaceutical Development, Farmak Joint-Stock Company, Frunze str., 63, Kyiv, Ukraine, 04080

E-mail: s.gureeva@farmak.ua

Olga Yuryeva, Central Laboratory of Pharmaceutical Development, Farmak Joint-Stock Company, Frunze str., 63, Kyiv, Ukraine, 04080

E-mail: o.yuryeva@farmak.ua 